\title{
鉛フリー半導体パッケージのはんだ付け実装における ウィスカ評価
}

\author{
小林 晶子*，戸井 恵子*，梶原 隆志 ${ }^{* *}$ ，竹内 誠 ${ }^{* * *}$, 高橋 邦明***
}

Whisker Test of Lead-Free Semiconductor Packages in Lead-Free Soldering

Akiko KOBAYASHI* , Keiko TOI*, Takashi KAJIHARA**, Makoto TAKEUCHI*** and Kuniaki TAKAHASHI ${ }^{* * *}$

*エスペック株式会社横浜 R\&D センター（２24-0053＼cjkstart神奈川県横浜市都筑区池辺町 4206）

**エスペックテストセンター株式会社豊田試験所（† 471-0844 愛知県豊田市聖心町 3-44-1）

***エスペックテストセンター株式会社横浜試験所（テ224-0053 神奈川県横浜市都筑区池辺町 4206）

* Yokohama R\&D Center, ESPEC CORP. (4206 Ikonobe-cho, Tsuduki-ku, Yokohama-shi, Kanagawa 224-0053)

** Toyota Test Center, ESPEC TEST CENTER CORP. (3-44-1 Seishin-cho, Toyota-shi, Aichi 471-0844)

***Yokohama Test Center, ESPEC TEST CENTER CORP. (4206 Ikonobe-cho, Tsuduki-ku, Yokohama-shi, Kanagawa 224-0053)

\begin{abstract}
We evaluated the semiconductor mounting substrate and investigated the whisker's generations and factors by experimenting different environmental conditions. On the lead consisted of $\mathrm{Cu}$ base/Sn plating, the result of the condition $110^{\circ} \mathrm{C} / 85 \% \& 120^{\circ} \mathrm{C} / 85 \%$ which were produced by AirHAST (HAST with air) generates Sn whiskers faster than other high temperature and humidity tests. We concluded that the factors in the whisker generation are high temperatures, high moisture and oxygen.
\end{abstract}

Key Words: Sn/Tin Whisker, Lead-Free Solder, QFP, Soldering, Environmental Testing

\section{1. 緒 言}

電子部品の鉛フリー化によって，電子部品のリード間で 発生するウィスカによるショート故障が懸念されている。 錫ウィスカは，主に下記の 5 種類の環境条件で発生・成長 することが知られている1)。

室温で成長するウィスカ

温度サイクルで成長するウィスカ

酸化・腐食環境で成長するウィスカ

外圧下で成長するウィスカ

エレクトロマイグレーションで成長するウィスカ

このうち本稿では，温湿度がかかわる，室温，温度サイ クル，酸化・腐食環境で成長するウィスカに焦点を当てた。 電子部品のウィスカ評価としては, 室温試験 4000 時間, 高温高湿試験 2000 時間, 温度サイクル試験 2000 サイクル などが実施されている ${ }^{2}$ が，長時間を要するため，短時間 で評価可能な試験方法が求められている。また，めっき， はんだ，部品，リードフレームなど，各単体でのウィスカ 評価報告は多いが，半導体パッケージ実装基板での評価は あまり報告されていない。そこで，半導体パッケージ (QFP) 実装基板において各種環境試験を実施した。

環境試験は，室温試験，温度サイクル試験(TC), 高温高 湿試験，高度加速寿命試験(HAST: Highly-Accelerated Temperature and Humidity Stress Test)や，さらに，酸化の要因
検討のため，空気分圧を変えた特殊な試験を実施した。 試験後は，QFPリード部のマイクロスコープ観察，SEM (Scanning Electron Microscope) 観察および EPMA (Electron Probe Micro Analyzer)分析から，リードはんだ付け部の外 観変化とその原因について解析を行い，短時間でウィスカ 発生を評価可能な試験方法の検討を行った。

\section{2. 評価方法}

\section{1 半導体パッケージ実装基板}

評価基板は， $\mathrm{QFP}$ パッケージを $\mathrm{Sn}-3.0 \mathrm{Ag}-0.5 \mathrm{Cu}$ はんだ ペーストを用いてリフローはんだ付けした基板を用いた。 Table 1 に評価基板の詳細，Fig. 1 に外観写真を示す。QFP

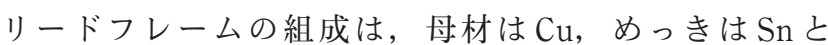
$\mathrm{Ni}-\mathrm{Pd}-\mathrm{Au}$ の 2 種類を用いた (Table 2)。

\section{2 環境試験および観察}

Table 3 に実施した環境試験条件を示す。環境試験は室温 試験（17.9 27.5 ${ }^{\circ} \mathrm{C} 12 \sim 68 \% \mathrm{rh}$ ，平均： $24.8^{\circ} \mathrm{C} 40 \% \mathrm{rh}$ ），温 度サイクル試験（保持時間 15 分），高温高湿試験，高度加 速寿命試験(HAST) を実施した。高温高湿試験については, 一般的な試験装置(Table 3 (7) と，減圧することで空気分圧 をほぼ $0 \mathrm{kPa}$ (圧力単位：パスカル）とした特殊仕様の試 験装置(Table 3 8) を用いた。また，通常空気のないほぼ水 蒸気のみの環境の, 標準の HAST 試験 (Table 3 (12) ) と, HAST 槽内に空気を残す，特殊仕様の HAST 槽を用いた試 
験（以下Air-HAST と呼ぶ）(Table 3 (10) の両方を実施した。 Fig. 2 にHAST と Air-HAST の試験開始時の温度・湿度・圧 力のプロファイルを示す。これらから, 空気中の酸素によ

Table 1. Evaluation board

\begin{tabular}{l|l}
\hline Package & $0.5 \mathrm{~mm}$ pitch, $176 \mathrm{pin}, \mathrm{QFP}$ \\
\hline PWB specifications & FR-4 $46 \mathrm{~mm} \times 46 \mathrm{~mm} \times 0.8 \mathrm{~mm}$ \\
\hline Solder alloy & $\mathrm{Sn}-3.0 \mathrm{Ag}-0.5 \mathrm{Cu}$ \\
\hline Peak reflow temperature & $240^{\circ} \mathrm{C}$ \\
\hline
\end{tabular}

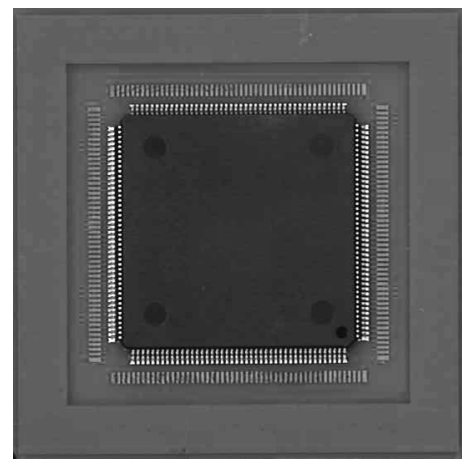

Fig. 1 Evaluation board

Table 2. Lead frame

\begin{tabular}{c|c|c}
\hline Base metal & Plating & Plating thickness \\
\hline $\mathrm{Cu}$ & $\mathrm{Sn}$ & $10 \mu \mathrm{m}$ \\
\hline \multirow{2}{*}{$\mathrm{Cu}$} & & $\mathrm{Ni}: 1.17 \mu \mathrm{m}$ \\
& $\mathrm{Ni}-\mathrm{Pd}-\mathrm{Au}$ & $\mathrm{Pd}: 0.03 \mu \mathrm{m}$ \\
& & $\mathrm{Au}: \mathrm{Flash}$ \\
\hline
\end{tabular}

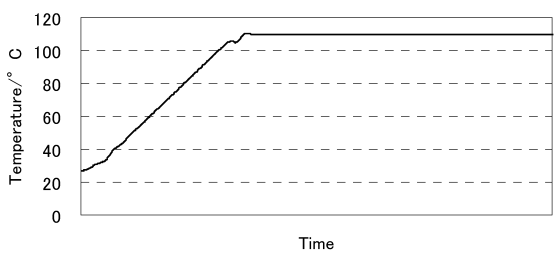

(a) Temperature profile of HAST

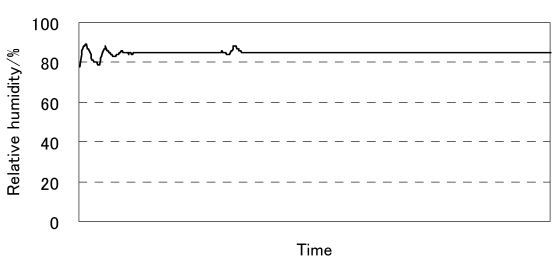

(c) Relative humidity profile of HAST

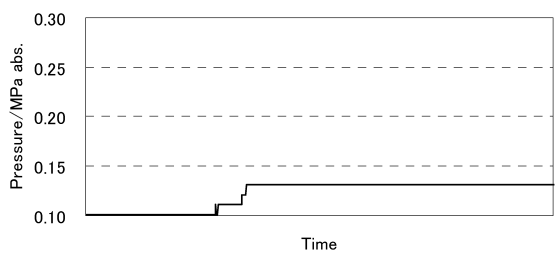

(e) Absolute pressure profile of HAST
る酸化の影響と，水蒸気による酸化の影響を分けて調査し た。任意の試験時間後は，サンプルを取り出し，リード部 のマイクロスコープおよびSEM 観察を行った。観察後は,

Table 3. Test conditions

\begin{tabular}{|c|c|c|c|}
\hline & Test method & Test conditions & Apparatus \\
\hline (1) & Ambient test & $\begin{array}{l}17.9 \sim 27.5^{\circ} \mathrm{C} / 12 \sim 68 \% \mathrm{rh} \\
\text { (Average: } 24.8^{\circ} \mathrm{C} / 40 \% \mathrm{rh} \text { ) }\end{array}$ & \\
\hline (2) & Temperature cycling test & $0^{\circ} \mathrm{C} / 60^{\circ} \mathrm{C} ; 15$ minute-soak & \\
\hline (3) & Temperature cycling test & $-40^{\circ} \mathrm{C} / 85^{\circ} \mathrm{C} ; 15$ minute-soak & \\
\hline (4) & Temperature cycling test & $-40^{\circ} \mathrm{C} / 125^{\circ} \mathrm{C} ; 15$ minute-soak & \\
\hline (5) & $\begin{array}{l}\text { High Temperature/ } \\
\text { Humidity test }\end{array}$ & $55^{\circ} \mathrm{C} / 85 \% \mathrm{rh}$ & \\
\hline (6) & $\begin{array}{l}\text { High Temperature/ } \\
\text { Humidity test }\end{array}$ & $60^{\circ} \mathrm{C} / 93 \% \mathrm{rh}$ & \\
\hline (7) & $\begin{array}{l}\text { High Temperature/ } \\
\text { Humidity test }\end{array}$ & $85^{\circ} \mathrm{C} / 85 \% \mathrm{rh}$ & \\
\hline (8) & $\begin{array}{l}\text { High Temperature/ } \\
\text { Humidity test }\end{array}$ & $\begin{array}{c}85^{\circ} \mathrm{C} / 85 \% \mathrm{rh} \\
\mathrm{APP}^{*}=0 \mathrm{kPa} \text { in estimate }\end{array}$ & Special \\
\hline (9) & $\begin{array}{l}\text { High Temperature/ } \\
\text { Humidity test }\end{array}$ & $85^{\circ} \mathrm{C} / 95 \% \mathrm{rh}$ & \\
\hline (10) & Air-HAST & $110^{\circ} \mathrm{C} / 85 \% \mathrm{rh}, \mathrm{APP}=128 \mathrm{kPa}$ in theory & Special \\
\hline (11) & Air-HAST & $120^{\circ} \mathrm{C} / 85 \% \mathrm{rh}, \mathrm{APP}=132 \mathrm{kPa}$ in theory & Special \\
\hline (12) & HAST & $110^{\circ} \mathrm{C} / 85 \% \mathrm{rh}, \mathrm{APP}=0 \mathrm{kPa}$ in estimate & Standard \\
\hline (13) & HAST & $120^{\circ} \mathrm{C} / 75 \% \mathrm{rh}, \mathrm{APP}=0 \mathrm{kPa}$ in estimate & Standard \\
\hline (14) & HAST & $120^{\circ} \mathrm{C} / 85 \% \mathrm{rh}, \mathrm{APP}=0 \mathrm{kPa}$ in estimate & Standard \\
\hline
\end{tabular}

* APP: Air Partial Pressure

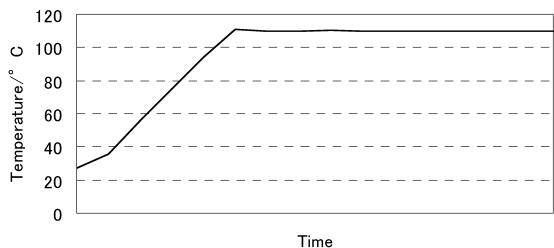

(b) Temperature profile of Air-HAST

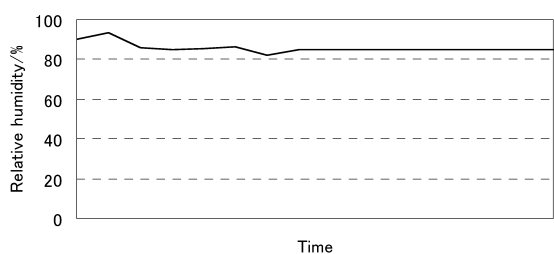

(d) Relative humidity profile of Air-HAST

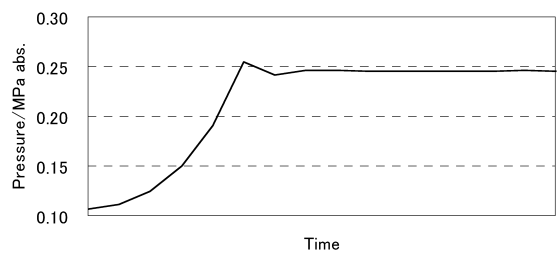

(f) Absolute pressure profile of Air-HAST

Fig. 2 Temperature, relative humidity, and absolute pressure profiles of HAST and Air-HAST after starting up $\left(110^{\circ} \mathrm{C} / 85 \% \mathrm{rh}\right)$ 
同じサンプルを再び試験に投入した。

\section{3. 評価結果および考察}

\section{1 評価結果}

試験後の外観変化として, 針状ウィスカ, ノジュール,

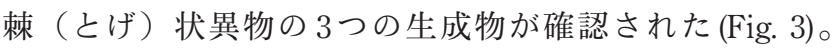
Table 4, 5 にSnめっきリードおよび Ni-Pd-Auめっきリード
の環境試験後の観察結果を示す。両めっきリードと屯に, $85^{\circ} \mathrm{C} / 85 \% \mathrm{rh}$ より高温高湿の環境において, リード先端から 棘状異物の発生を確認した。また，Snめっきリードは，高 温高湿試験(6) $60^{\circ} \mathrm{C} / 93 \% \mathrm{rh} \sim(9) 85^{\circ} \mathrm{C} / 95 \% \mathrm{rh}$ および Air-HAST (10) $110^{\circ} \mathrm{C} / 85 \% \mathrm{rh}$ (11) $120^{\circ} \mathrm{C} / 85 \% \mathrm{rh}$ で， ウィスカの発生を確認 した。 $\mathrm{Ni}-\mathrm{Pd}-\mathrm{Au}$ めっきードは，高温高湿試験 (5) $55^{\circ} \mathrm{C} / 85 \% \mathrm{rh} \sim 7785^{\circ} \mathrm{C} / 85 \% \mathrm{rh}$ で， ウィスカの発生を確認し

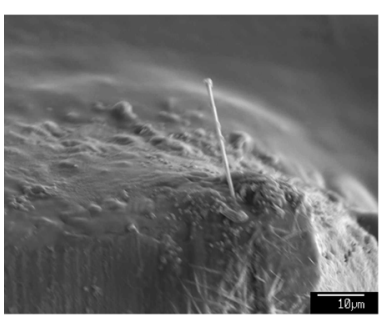

(a) Filament whisker

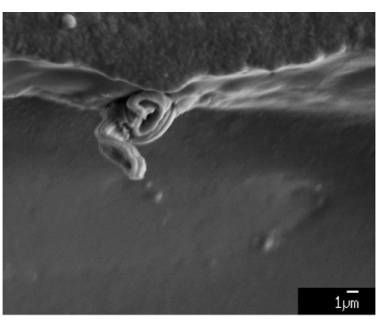

(b) Nodule

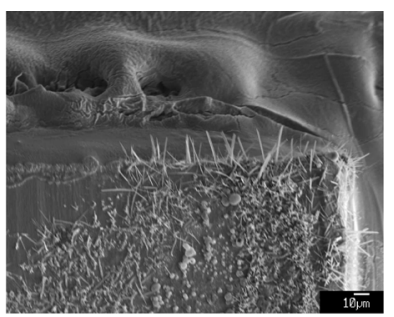

(c) Thorn-like protrusions

Fig. 3 Appearance of QFP lead after environmental testing (SEM)

Table 4. Test results (Sn Plating)

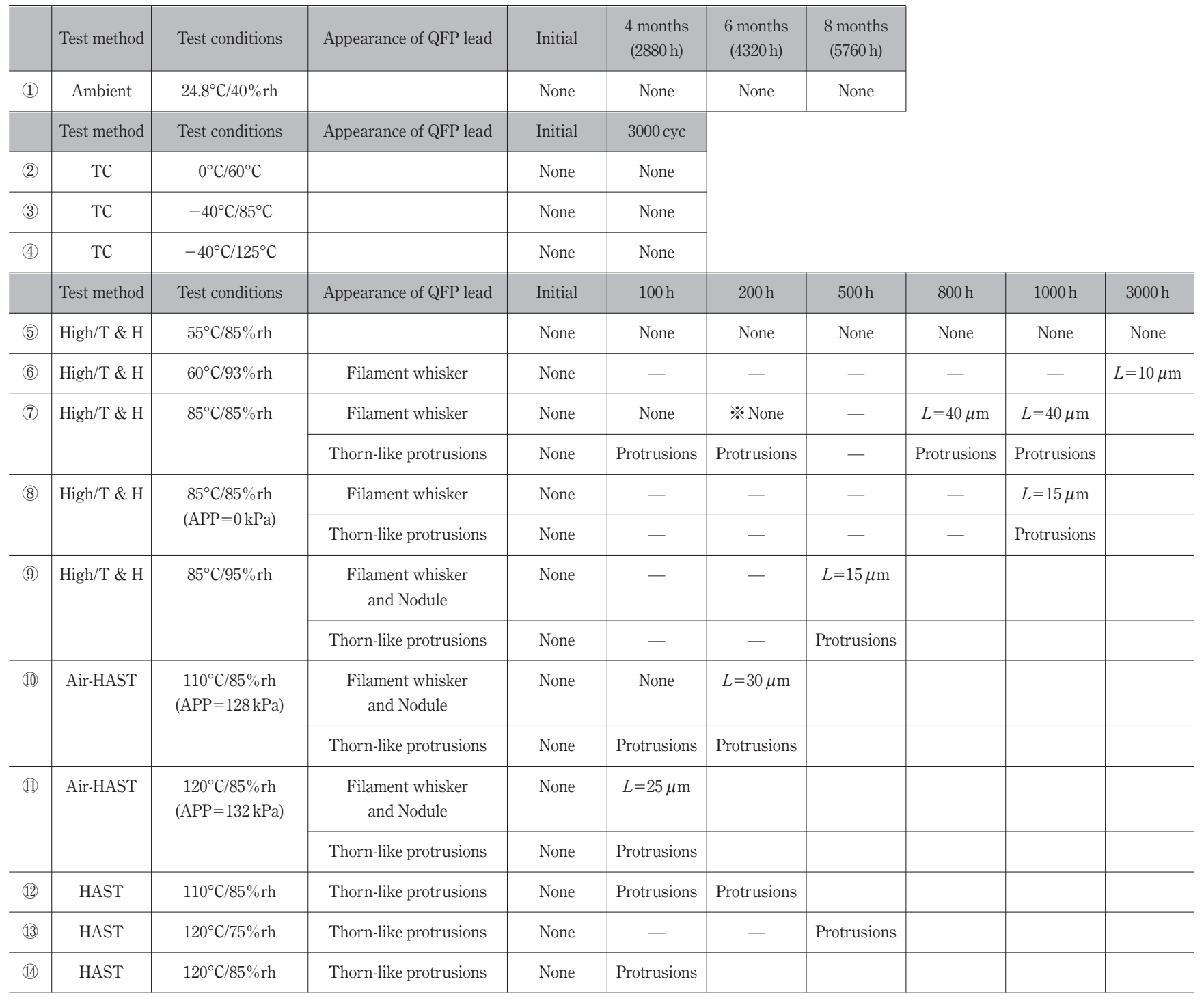

APP: Air Partial Pressure $\quad-$ : Unadministered Length: Max whisker length

$\mathrm{N}=352$-pin (2-board) $\quad \%: \mathrm{N}=176$-pin (1-board) 
Table 5. Test results (Ni-Pd-Au Plating)

\begin{tabular}{|c|c|c|c|c|c|c|c|c|c|c|}
\hline & Test method & Test conditions & Appearance of QFP lead & Initial & $\begin{array}{l}4 \text { months } \\
(2880 \mathrm{~h})\end{array}$ & $\begin{array}{l}6 \text { months } \\
(4320 \mathrm{~h})\end{array}$ & $\begin{array}{l}8 \text { months } \\
(5760 \mathrm{~h})\end{array}$ & & & \\
\hline \multirow[t]{2}{*}{ (1) } & Ambient & $24.8^{\circ} \mathrm{C} / 40 \% \mathrm{rh}$ & & None & None & None & None & & & \\
\hline & Test method & Test conditions & Appearance of QFP lead & Initial & 3000 сус & & & & & \\
\hline (2) & $\mathrm{TC}$ & $0^{\circ} \mathrm{C} / 60^{\circ} \mathrm{C}$ & & None & None & & & & & \\
\hline (3) & $\mathrm{TC}$ & $-40^{\circ} \mathrm{C} / 85^{\circ} \mathrm{C}$ & & None & None & & & & & \\
\hline \multirow[t]{2}{*}{ (4) } & $\mathrm{TC}$ & $-40^{\circ} \mathrm{C} / 125^{\circ} \mathrm{C}$ & & None & None & & & & & \\
\hline & Test method & Test conditions & Appearance of QFP lead & Initial & $100 \mathrm{~h}$ & $200 \mathrm{~h}$ & $500 \mathrm{~h}$ & $800 \mathrm{~h}$ & $1000 \mathrm{~h}$ & $3000 \mathrm{~h}$ \\
\hline (5) & High/T \& H & $55^{\circ} \mathrm{C} / 85 \% \mathrm{rh}$ & $\begin{array}{l}\text { Filament whisker } \\
\text { and Nodule }\end{array}$ & None & - & - & - & - & - & $L=15 \mu \mathrm{m}$ \\
\hline \multirow[t]{2}{*}{ (6) } & $\mathrm{High} / \mathrm{T} \& \mathrm{H}$ & $60^{\circ} \mathrm{C} / 93 \% \mathrm{rh}$ & $\begin{array}{l}\text { Filament whisker } \\
\text { and Nodule }\end{array}$ & None & - & - & - & - & - & $L=50 \mu \mathrm{m}$ \\
\hline & & & Thorn-like protrusions & None & - & - & - & - & - & Protrusions \\
\hline \multirow[t]{2}{*}{ (7) } & High/T \& H & $85^{\circ} \mathrm{C} / 85 \% \mathrm{rh}$ & Filament whisker & None & None & $※$ None & - & $L=30 \mu \mathrm{m}$ & $L=30 \mu \mathrm{m}$ & \\
\hline & & & Thorn-like protrusions & None & Protrusions & Protrusions & - & Protrusions & Protrusions & \\
\hline (8) & $\mathrm{High} / \mathrm{T} \& \mathrm{H}$ & $\begin{array}{l}85^{\circ} \mathrm{C} / 85 \% \mathrm{rh} \\
(\mathrm{APP}=0 \mathrm{kPa})\end{array}$ & Thorn-like protrusions & None & - & - & - & - & Protrusions & \\
\hline (9) & $\mathrm{High} / \mathrm{T} \& \mathrm{H}$ & $85^{\circ} \mathrm{C} / 95 \% \mathrm{rh}$ & & None & - & - & None & & & \\
\hline (10) & Air-HAST & $\begin{array}{c}110^{\circ} \mathrm{C} / 85 \% \mathrm{rh} \\
(\mathrm{APP}=128 \mathrm{kPa})\end{array}$ & Thorn-like protrusions & None & Protrusions & Protrusions & & & & \\
\hline (11) & Air-HAST & $\begin{array}{c}120^{\circ} \mathrm{C} / 85 \% \mathrm{rh} \\
(\mathrm{APP}=132 \mathrm{kPa})\end{array}$ & Thorn-like protrusions & None & Protrusions & & & & & \\
\hline (12) & HAST & $110^{\circ} \mathrm{C} / 85 \% \mathrm{rh}$ & Thorn-like protrusions & None & Protrusions & ※Protrusions & & & & \\
\hline (13) & HAST & $120^{\circ} \mathrm{C} / 75 \% \mathrm{rh}$ & Thorn-like protrusions & None & - & - & Protrusions & & & \\
\hline (14) & HAST & $120^{\circ} \mathrm{C} / 85 \% \mathrm{rh}$ & Thorn-like protrusions & None & Protrusions & & & & & \\
\hline
\end{tabular}

APP: Air Partial Pressure $\quad-$ : Unadministered $\quad L$ : Max whisker length $\mathrm{N}=704$-pin (4-board) $\quad ※: \mathrm{N}=176$-pin (1-board)

た。両めっきリードともに, 室温試験 8 力月 $(5760 \mathrm{~h})$ および 温度サイクル試験 3000 cycで, ウィスカの発生はなかった。

\section{2 ウィスカ発生・成長要因}

Table 4 より, 高温高湿の環境において, 温度・湿度が高 いほどウィスカが発生・成長しやすい傾向があった。

また, Table 4 より, Snめっきリードでは, (5) $55^{\circ} \mathrm{C} /$ 85\%rh/3000hでウィスカが発生しなかったのに対し, AirHAST (10) $110^{\circ} \mathrm{C} / 85 \% \mathrm{rh} / 200 \mathrm{~h}$ や(11) $120^{\circ} \mathrm{C} / 85 \% \mathrm{rh} / 100 \mathrm{~h}$ では短 時間でウィスカが発生したことからこれらの Air-HAST の試験条件は短時間でウィスカ評価できる可能性がある。 また, HAST (12) $110^{\circ} \mathrm{C} / 85 \% \mathrm{rh} / 200 \mathrm{~h}$ ではウィスカは発生しな かったことから， Air-HAST (10) $110^{\circ} \mathrm{C} / 85 \% \mathrm{rh}$ とHAST (12) $110^{\circ} \mathrm{C} / 85 \% \mathrm{rh}$ の違いを調査するため, ウィスカの主な発生 箇所である，リード先端の断面の元素分析を行った(Fig. 4)。 元素分析結果では, Air-HAST (Fig. 4(a))の方がHAST (Fig. 4(b))より, リード先端のSnの酸化が顕著であった。Snは, 酸化によって体積膨張や歪みが生じ, 圧縮応力を発生す る1)。したがって, Air-HAST 環境に存在する酸素が, ウィ
スカ発生に寄与したと考えられる。特にリード先端におい て酸化が進行しているのは, リード先端は母材の $\mathrm{Cu}$ が露 出しており, $\mathrm{Cu}$ と $\mathrm{Sn}$ の間でガルバニック電池を形成する ためと考えられる。

\section{3 ウィスカの分析}

Fig. 5 に Air-HAST (10 $110^{\circ} \mathrm{C} / 85 \% \mathrm{rh}$ 試験後の Snめっき リード先端の観察結果を示す。リード先端から約 $30 \mu \mathrm{m}$ の 針状ウィスカが発生した。Sn元素分析結果では，このウィ スカの主成分は Snであった (Fig. 5(c))。また, Fig. 6 に(7) $85^{\circ} \mathrm{C} / 85 \% \mathrm{rh}$ 試験後の Ni-Pd-Auめっきリードの観察結果を 示す。リード側面から約 $20 \mu \mathrm{m}$ の針状ウィスカが発生した。 $\mathrm{Sn}$ 元素分析結果では，このウィスカの主成分も Snであっ た(Fig. 6(c))。Ni-Pd-Auめっきには Snが含まれないことか ら，このウィスカの主成分は，はんだ中の $\mathrm{Sn}$ と考えられ る。

\section{4 棘状異物の分析}

棘状異物は主にリード先端に発生していた。Snめっき リード上の棘状異物の元素分析結果を Fig. 7 に示す。さら 


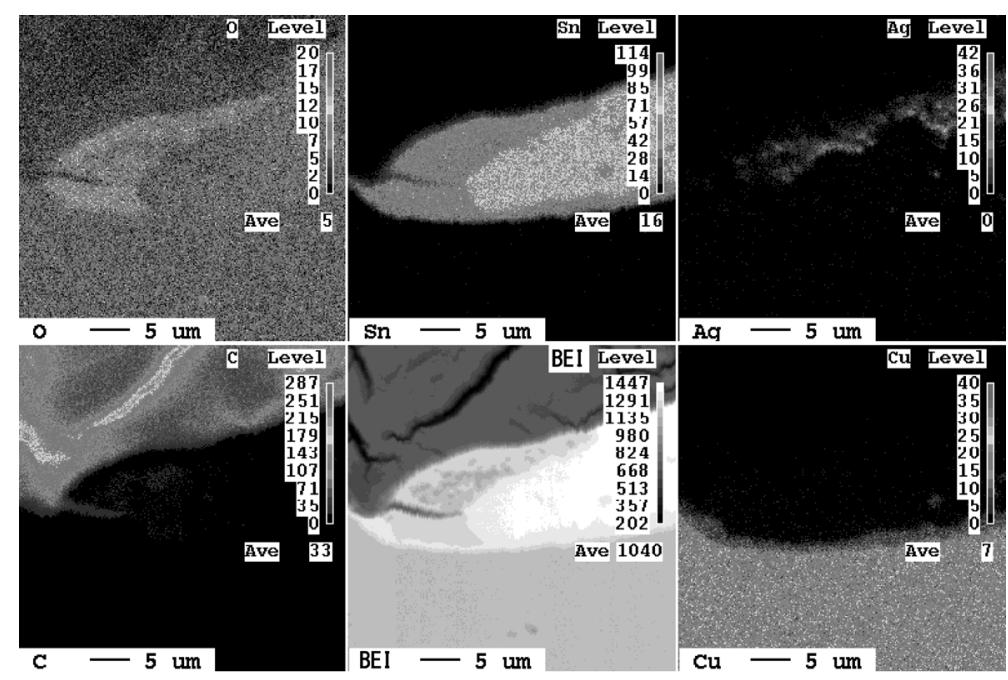

(a) Air-HAST $110^{\circ} \mathrm{C} / 85 \% \mathrm{rh} / 200 \mathrm{~h}$ APP $=128 \mathrm{kPa}$, Sn plating

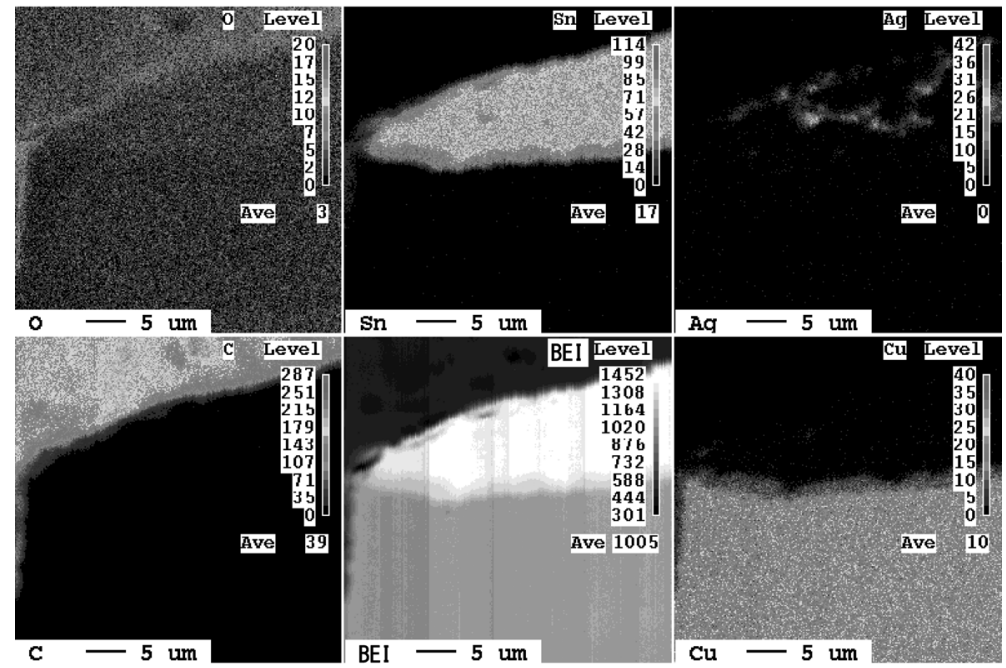

(b) HAST $110^{\circ} \mathrm{C} / 85 \% \mathrm{rh} / 200 \mathrm{~h}$ APP $=0 \mathrm{kPa}$, Sn plating

Fig. 4 Analyzed toe of QFP lead (EPMA)

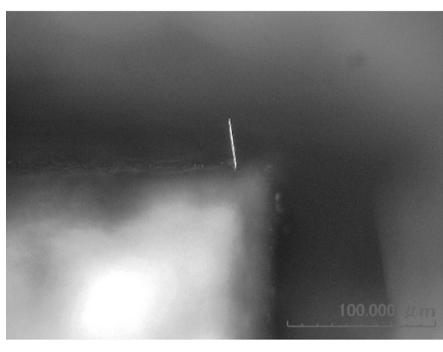

(a) Microscope

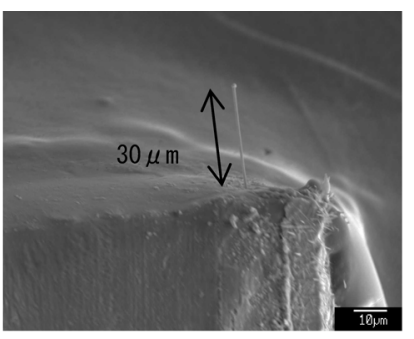

(b) SEM

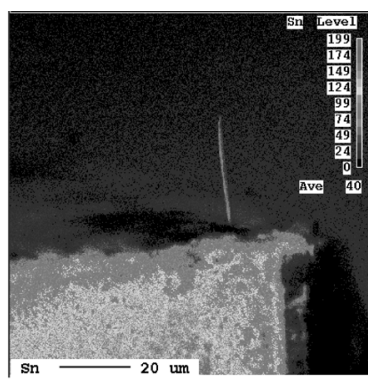

(c) EPMA (Sn)

Fig. 5 Observed whisker (Sn Plating, Air-HAST $110^{\circ} \mathrm{C} / 85 \% \mathrm{rh} / 200 \mathrm{~h}$ APP $=128 \mathrm{kPa}$ )

に，分析精度を高めるため，棘状異物をカーボンテープに 貼り，元素分析を行った結果を Fig. 8 に示す。棘状異物か らは $\mathrm{Cu}$ や C, O, Br が検出され, Sn は検出されなかった。 $\mathrm{Cu}$ はリードフレーム母材, $\mathrm{C}, \mathrm{O}, \mathrm{Br}$ はフラックスに含まれるこ
とから，棘状異物はリード端部に露出した銅とフラックス によって形成された塩と推察され，単結晶のウィスカでは なかった。棘状異物はウィスカと形状が類似しているため, 観察の際に注意が必要である。 


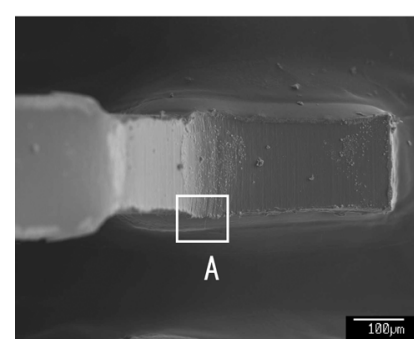

(a) SEM

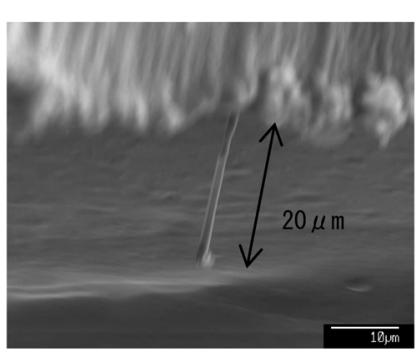

(b) SEM (Enlarged A site)

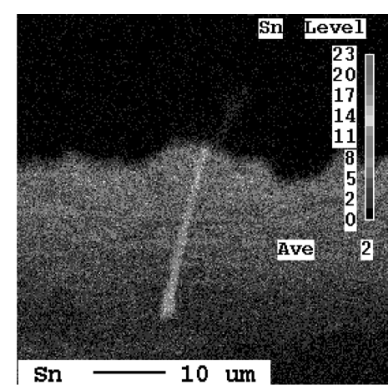

(c) EPMA (Sn)

Fig. 6 Observed whisker (Ni-Pd-Au Plating, $85^{\circ} \mathrm{C} / 85 \% \mathrm{rh} / 1000 \mathrm{~h}$ )

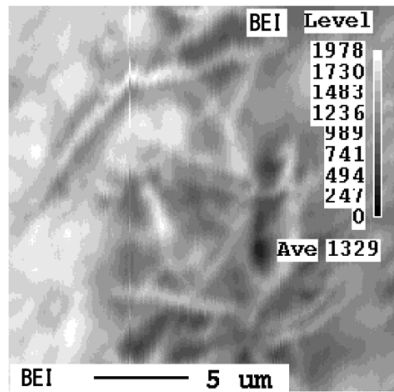

(a) BEI

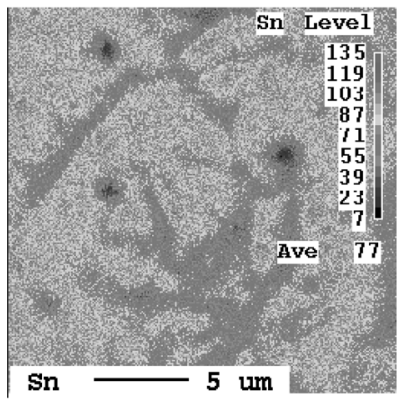

(d) EPMA (Sn)

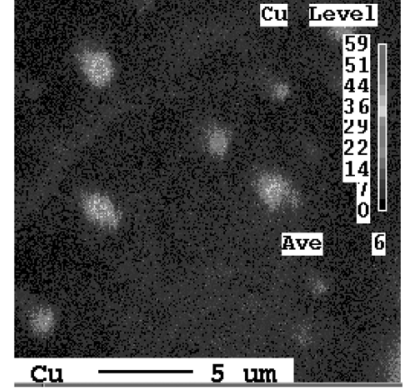

(b) EPMA (Cu)

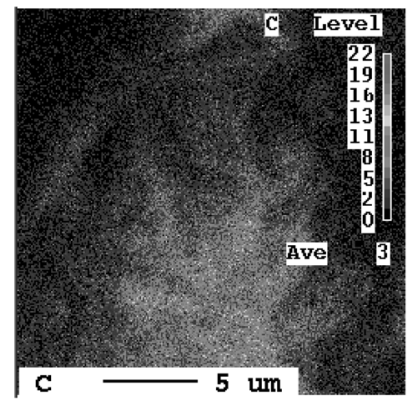

(e) EPMA (C)

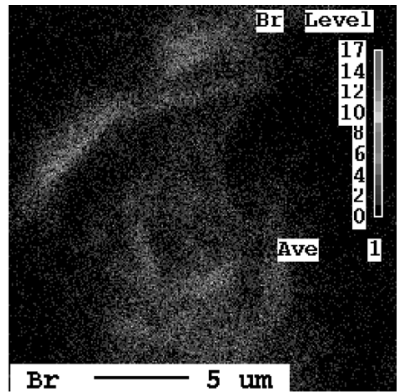

(c) EPMA (Br)

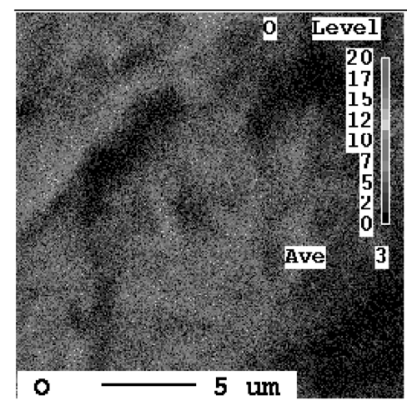

(f) EPMA (0)

Fig. 7 Analyzed thorn-like protrusions (Sn Plating, HAST $120^{\circ} \mathrm{C} / 85 \% \mathrm{rh} / 200 \mathrm{~h}$ )

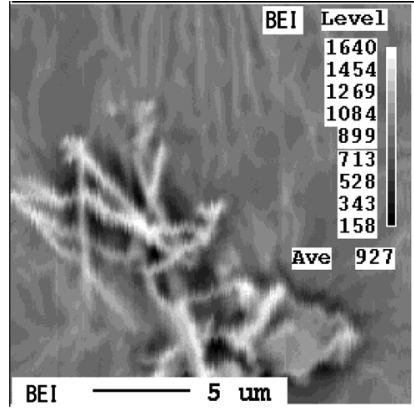

(a) BEI

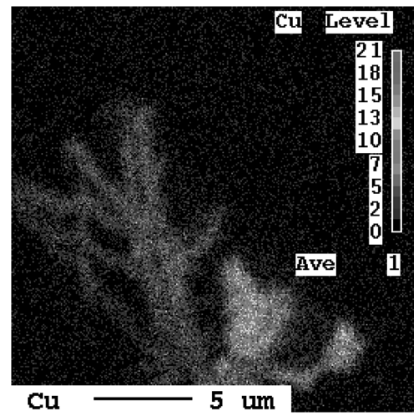

(b) EPMA (Cu)

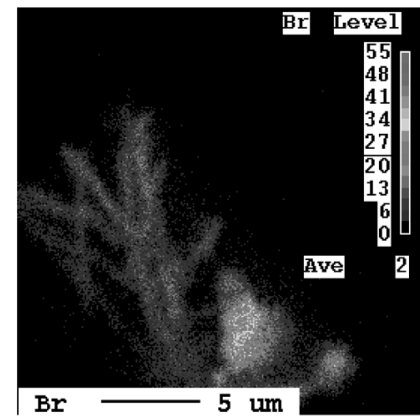

(c) EPMA (Br)

Fig. 8 Analyzed thorn-like protrusions (Ni-Pd-Au Plating, HAST $120^{\circ} \mathrm{C} / 75 \% \mathrm{rh} / 500 \mathrm{~h}$ )

\section{4. 結 言}

短時間でウィスカ評価可能な試験方法を調査するため, 半導体パッケージ実装基板において, 室温試験, 温度サイ クル試験, 高温高湿試験, 高度加速寿命試験 (HAST)や, さらに, 酸化の要因検討のため, 空気分圧を変えた特殊な
試験を実施し，次の結論を得た。

(1) 酸化・腐食環境で成長するウィスカの発生・成長要 因として，高温，高湿および酸素が関与していると 考えられる。

(2) Air-HAST（HAST 槽内に空気を残す，特殊仕様の HAST槽を用いた試験） $110^{\circ} \mathrm{C} / 85 \% \mathrm{rh}$ および 
$120^{\circ} \mathrm{C} / 85 \% \mathrm{rh}$ は, 酸化・腐食環境で成長するウィス カを短時間で評価できる可能性がある。

（3）めっきにSnが含まれない半導体パッケージ実装基板 でもSn ウィスカが発生したことから, 今回発生した ウィスカは，はんだウィスカと考えられる。

(4) 高温高湿環境でリード先端に発生した棘状異物は, リード端部に露出した銅とフラックスによって形成 された塩と推察され，単結晶のウィスカではないが, ウィスカと形状が類似しているため, 観察の際に注 意が必要である。

（2009.9.9-受理）

\section{文献}

1）菅沼克昭：“Snウィスカ発生メカニズム理解の現状と抑制 技術”，エレクトロニクス実装学会講演大会講演論文集, Vol. 21, March, pp. 19-20, 2007年3月

2) IEC60068-2-82, "Environmental Testing-Part 2-82: Tests—Test Tx: Whisker Test Methods for Electronic and Electric Components"

3) 小林晶子, 戸井恵子, 梶原隆志, 竹内 誠, 高橋邦明 : “鉛フリー半導体パッケージのはんだ付け実装におけるウィ スカ評価”，エレクトロニクス実装学会講演大会講演論文 集，Vol. 23, March, pp. 165-166, 2009年3月 